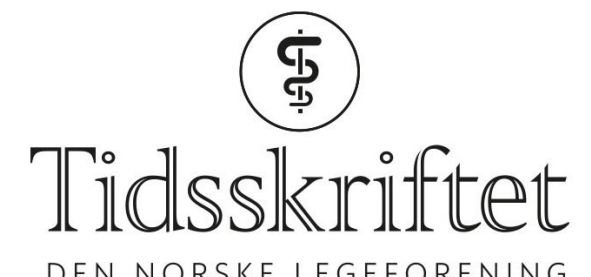

DEN NORSKE LEGEFORENING

\title{
Velkommen, kjære kollega
}

MINILEDER

\section{ARE BREAN}

Sjefredaktør

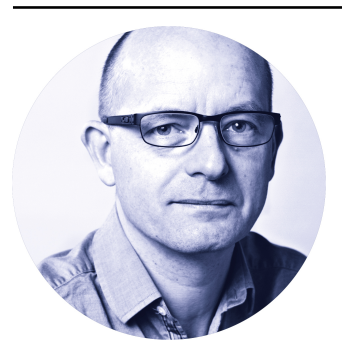

I disse dager begynner hundrevis av nye norske legestudenter på den mangeårige veien mot sitt fremtidige yrke. Selv om studiet fortsatt er prestisjetungt, er legerollen som vil møte dem i endring. Elendighetsbeskrivelsene er mange: Mangel på turnusplasser. Press mot faglig autonomi. Tap av privilegier og posisjon. En åpent fiendtlig arbeidsgiverside $\mathrm{i}$ sykehus. Stadig nye og medisinsk perifere oppgaver i kommunene. Og som alltid advares det mot overproduksjon av leger.

Som nyslått legestudent bør du ikke høre for mye på elendighetsbeskrivelsene. Der det er endring, er det også muligheter. For faget du har valgt, vil fortsatt være ett av verdens mest mangslungne. Legeutdanningen vil gi deg en unik base av akademisk kompetanse, menneskekunnskap og kritisk sans. Den vil gjøre deg i stand til å arbeide blant så vel reagensrør som blant bøker eller i flyktningeleirer. Og i en tid der aggressive bølger av nasjonalisme og rop om stengte grenser skyller over hele den vestlige verden, er det et privilegium å tilhøre en yrkesgruppe og et fag som alltid har vært internasjonalt. Medisinfaget kjenner ingen grenser. Det vil også i fremtiden være en styrke.

Men selv med et hav av andre muligheter vil de fleste av dine kullkamerater velge å bli klinikere. Å anvende akademisk kunnskap om det teoretiske og generelle mennesket til å diagnostisere og behandle det enkelte og unike mennesket er legekunstens essens og yrkets kjerne. Daglig å kunne strekke seg etter å omgjøre stringent og distansert vitenskap til nær og konkret hverdagskunst er svært få andre yrkesgrupper forunt.

Uansett valg av retning for din legegjerning vil kontinuerlig lesing og faglig oppdatering være viktig. Derfor markerer vi i Tidsskriftet som vanlig studiestarten med å gi ut et eget utdanningsnummer. Det er mer innholdsrikt enn på lenge og gjenspeiler den myldrende aktiviteten i det faget du er på vei inn i. Legeyrket er et av verdens mest spennende og givende yrker. Gratulerer med et godt valg av studium. 
Publisert: 21. august 2017. Tidsskr Nor Legeforen. DOI: 10.4045/tidsskr.17.14.04 (c) Tidsskrift for Den norske legeforening 2020. Lastet ned fra tidsskriftet.no 